\title{
The Role of Microfinance in Poverty Alleviation: Empirical Evidence from South-West Nigeria
}

\author{
Taofeek Aremu Kasali ${ }^{1}$, Siti Aznor Ahmad ${ }^{1} \&$ Hock Eam Lim ${ }^{1}$ \\ ${ }^{1}$ Department of Economics \& Agribusiness, School of Economics, Finance \& Banking, UUM-COB, Malaysia \\ Correspondence: Taofeek Aremu Kasali, Department of Economics and Agribusiness, School of Economics, \\ Finance and Banking, UUM-COB, Malaysia. Tel: 60-16-214-7461. E-mail: taofeekkasali2012@gmail.com
}

Received: April 15, $2015 \quad$ Accepted: May 13, $2015 \quad$ Online Published: July 6, 2015
$\begin{aligned} & \text { doi:10.5539/ass.v11n21p183 } \\ & \text { URL: http://dx.doi.org/10.5539/ass.v11n21p183 }\end{aligned}$

\begin{abstract}
Microfinance programme has been generally regarded as a development strategy that can enhance the economic performance of the poor. The government of Nigeria has made concerted efforts to alleviate poverty in the country. One of such efforts is Poverty alleviation through Microfinance loan but poverty still remains pervasive and widespread in the country especially in the rural communities. This study examines the role of microfinance vis-à-vis poverty reduction particularly in the South- West Zone of Nigeria. Data were collected through survey questionnaire in the study area. Descriptive Statistics together with Binary Logit Regression Model were employed to analyse the data collected. The result of the analyses revealed that microfinance loan made significant impact on the loan beneficiaries in the study area which lead to poverty reduction. The government is advised to provide more enabling environment to make Microfinance operations more effective in the country particularly in the rural areas. Microfinance Institutions are implored to create more awareness on their operations and make less stringent conditions for the loan accessibility.
\end{abstract}

Keywords: economic development, poverty, microfinance, survey, Nigeria

\section{Introduction}

In the past two decades, microfinance programmes have been considered by the development economists as one of the foremost strategies for poverty reduction. Although some researchers argue that Microfinance has not really succeeded in its role as grassroots economic developer in the sense that it has not been effective in reaching the poorest (Hulme \& Mosley, 1977). But others opine that the programme is capable of bringing the poor into the lime light if properly implemented. This debate creates the gap for independent researchers to further examine the impact of Microfinance on poverty alleviation as donors and practitioners may be biased in their assessment. It is therefore believed that this study will contribute to literature and further make clarification on this debate by examining the impact of microcredit on poverty alleviation using Nigeria, the most populous black nation in the world as a case study.

Poverty contributes to underdevelopment and its reduction leads to economic development. To be poor connotes deprivation from the basic necessities of life. In fact, poverty engenders inability to afford the minimum basic essentials like food, children education, good housing, healthcare and good clothing to mention few (Todaro \& Smith, 2011, p. 2). Suffice to say that the poor are being denied their share of the nation's resources and other necessities that are generally available in the society for their comfort.

Poverty is a worldwide socio-economic problem. Hence, its awareness is much more favored at the international level of finance and governance. For example, the World Bank, United Nations (UN) and International Monetary Fund (IMF) have developed various programmes and projects that would improve the life of the poor, ensure health improvement and sustainable growth and development (Ssewamala, Sperber, Zimmerman, \& Karimli, 2010).

Records have shown that about half of the world's population (about three billion people) lives on income of less than two dollars a day (Goel \& Rishi, 2012). It is also disheartening that one child out of five living in these poor communities does not live to see his or her fifth birthday! No wonder that the United Nations declared Millennium Development Goals (MDGs) in September 2000 to ensure global development. The major policy thrust of this program is to make life more meaningful to the poor and downtrodden. In essence, reduction of 
poverty and hunger constitute the basic root of all other problem issues focused on MDGs (Kalirajan \& Singh, 2009). Ironically, in Sub-Saharan Africa which is considered as the World's poorest region, the concept of poverty is relatively understudied and has attracted less attention in academic literature (Ssewamala, Sperber, Zimmerman, \& Karimli, 2010). To this effect, little efforts have been made to critically analyse the impact of microfinance programmes on poverty reduction, particularly in Sub-Saharan Africa.

This paper examines the contributions of microfinance towards the poverty reduction. It has been argued that the impoverished poor exist because of lack of access to finance which can engender their capability to develop their entrepreneurship skill and establish their enterprises. Developing finance that will be accessible to the poor would enhance their productivity and capability to procure assets and necessary facilities that can encourage productive investment. This will therefore reduce poverty as it is clear that the poor does not lack initiative but only constrained by finance.

It has also been asserted that the major constraint of the poor is lack of adequate capital from financial institutions because of high risk of inadequate collateral. This constraint hampers growth, increases the poverty level and leads to slow economic development. Provision of microcredit to the poor will therefore improve the financial capital that will increase their productivity, reduce unemployment, enhance income and savings; and eventually reduce poverty and inequality.

During the past three decades in Nigeria, efforts have been made by the Government, Non-Governmental Organisations and International Organisations to reduce poverty. To this end, the Nigerian government established several programmes to alleviate poverty. In 1972, the National Accelerated Food Production Programme was inaugurated to boost the food production through an on lending fund from the Nigeria Agricultural and Cooperative Bank. In 1976, Operation Feed the Nation was established to provide extension services to farmers in the rural areas. While The Green revolution programme of 1979 was to put an end to food importation and encourage the production of more crops and fiber. Others are: The Directorate of Food Road and Rural Infrastructure (DFRRI) in 1986, The Community Banks of Nigeria, The Peoples Bank, The Family Economic Advancement Programme (FEAP), The Mass Mobilization for Self-Reliance (MAMSER), the Better Life Programme (BLP), The Family Support Programme (FSP) in 1993, The National Directorate of Employment (NDE), The Petroleum Special Trust Fund (PTF), The Mass Transit Programme (MTP), The Agency for Mass Literacy, National Economic Empowerment and Development Strategy (NEEDS); and the Microfinance Banks.

Microfinance has been used on several occasions to reduce poverty, in rural areas in particular which are believed to harbour the poorest people in the world. It is an important aid that can improve the economic performance of the poor. The poor people need microfinance to improve their entrepreneurial skill and socio economic needs. But despite these efforts, the level of unemployment continued to rise, while poverty conditions remain unabated in the country.

In Nigeria, the proportion of the people living in poverty has increased tremendously. For instance in 1980, the magnitude of Nigerians living below the poverty line increased from $17.1 \mathrm{~m}(27.2 \%$ of $65 \mathrm{~m}$ total population) to $34.7 \mathrm{~m}$ in 1985 (46.3\% of the total population of $75 \mathrm{~m})$. The people living in poverty in 1992 were $39.2 \mathrm{~m}(42.7 \%$ of the total population of $91.5 \mathrm{~m})$. This figure increased to $67.1 \mathrm{~m}$ in $1996(65.6 \%$ of the total population of $102.3 \mathrm{~m})$. In 2004 , the people in poverty were $68.7 \mathrm{~m}(54.4 \%$ of the total population of $126.3 \mathrm{~m})$, the proportion of people living below property line rose sharply in 2010 to $112.47 \mathrm{~m}$ ( $69 \%$ of the estimated population of $163 \mathrm{~m})$ (National Bureau of Statistics, 2012).

It is against the backdrop of the above enumerated problems that this study is set to evaluate the contribution of microfinance to poverty alleviation in the study area and by extension in the entire Nigeria country. This study is also aimed at determining the impact of the microfinance loan on the beneficiaries against non-beneficiaries. It is also expected that this study will fill gap in literature as little efforts have been advanced to study the effect of microfinance loan on poverty alleviation as it affects the rural poor particularly in the study area. The justifications of this study therefore are to contribute to literature and proffer necessary policy implications for the Government, Microfinance Operators and other stakeholders. This is expected to contribute to the reduction of poverty and enhance economic development.

The rest of this study is divided into five sections. Following the introduction, section 2 reviews the past literature on the subject matter. Methodology of the study is discussed in section 3 while the results of the analysis are discussed in section 4. The conclusion of the study is treated in Section 5 and policy recommendations are also enumerated. 


\section{Review of Past Literature}

The concept of poverty reduction has attracted the attention of some scholars. Empirical studies have identified some variables like inflation, age, household size, health problem, lack of savings and inadequate assets as the major causes of poverty (Chaudhry, 2009; Roslan \& Abd Karim, 2009; Taylor \& Xiaoyun, 2012; Yusuf, Shirazi, \& MatGhani, 2013).

Microfinance has its antecedent in Bangladesh with the commencement of Grameen Bank project in 1974. Grameen Bank, usually referred to as Rural Bank was started by Muhammad Yunus, a Professor of the University of Chittagong (Bangladesh) in 1976. The bank mainly targeted rural women for its credit programmes. It introduced group lending strategy called social security to make credit available to the poor, usually denied by traditional banks due to the lack of physical collateral. Group lending operates through the principle of joint liability whereby the members of the group monitor the loan disbursement and payment. Default of a member implicates other members and the later pay from the joint resources to avoid future denial of loan to other members. This system especially aims to empower women and give them the opportunity to participate in household decisions. With the latter's success, several developed and developing countries adopted the concept of micro financing. For instance, on September 17 1987, Amanah Ikhtiar Malaysia (AIM) was inaugurated with the main aim of reducing poverty and increasing income of Bumiputera and Malays in particular, through microcredit called Ikhtiar financing scheme for poor households in rural areas.

It is also on record that the Microcredit Summit launched in 1997 the global campaign to expand the coverage of microfinance to 100 million of the world's poorest micro entrepreneurs by 2005 . Hence, the United Nations declared year 2005 as the International Year of Microcredit (El-Komi, 2010).

The concept of Microfinance is based on economic development strategy that aims at poverty reduction by providing financial services to the poor, low income earners households and micro-entrepreneurs that are deprived of getting the same services from the formal financial market. These services include savings, credit, insurance and other development services like health, education, human empowerment, skills, training and environmental protection.

Microfinance can also be described as the process of advancing small loans to the poor with the aim of financing cottage and small scale businesses that would provide adequate income to take care of the recipients' responsibilities. Microfinance Institutions which were originally designed to assist the poor households and advance credits to entrepreneurs also provide services like savings, rural credit, Agricultural credit, consumer credit and other financial services (Duku, 2002). Microfinance also connotes the procedure of making available very small range of financial services to the poor with the purpose of making them take up new opportunities and participate in productive activities. It is a development tool that makes possible the rendering of services like money transfers, savings opportunities, and credit and insurance services. Microfinance entails both financial and social intermediation. It is therefore an economic phenomenon that enhances the potentials of low income group.

Microcredit is a subset of microfinance. It finances microenterprises and poorest people that cannot afford to pledge collateral security to obtain loan from conventional banks. Therefore microcredit assists the poor to increase their standard of living and their family welfare through short term credit facility that can generate revenue activity.

Studies have revealed that countries with well-organized and efficient financial intermediaries recover faster from poverty and inequality than their counterpart with moribund financial development and uncoordinated microfinance services (Kalirajan \& Smith, 2009; Yang et al., 2011). Microfinance involves the rendering of financial services to the poor and low income earners together with their micro businesses. It is widely acclaimed that Microfinance can serve as an effective tool to solve poverty problem worldwide. It is an essential aid for increase in productivity of the poor and essential ingredient for economic development (Comim, 2007; Dowla \& Barna, 2006; Wright, 2000; Islam, 2007) cited in (El-Komi, 2010). However, Microfinance enhances standard of living if properly managed (Bashir et al., 2010; Muller \& Bibi, 2010).

The operation of Microfinance can only thrive if the repayment schedule is met promptly by the customers. Empirical studies have shown that loan repayment is determined by the quality of the beneficiaries and other factors like education, distance of the lender to the customer's business, amount of loan, duration of the loan, gender and sanction threat to the borrowers (Roslan \& Abd Karim, 2009; Smith, 2010; Tang \& Bhatt, 2002).

Studies have affirmed that the development of financial sector will go a long way to contribute to economic growth and development. Suffice to say that the development of viral and efficient financial instrument like 
microfinance to fund micro and small enterprises will generate more employment, improve the standard of living, health, education, savings and serve as a formidable measure to reduce poverty (Green, Kirkpatrick, \& Murinde, 2006). Also, in his study of the impact of microfinance on rural Area in Pakistan, Asghar (2012) affirms that Microfinance can serve as a strong tool to increase the income of the poor and education of his household. He concludes that income generated from the credit of microfinance will reduce poverty and increase both economic and social well beings.

Having identified Microfinance Institutions and programmes as the necessary development strategies to alleviate poverty and assist the growth of micro and small enterprises; the financial institutions, the donor agencies, the Non- government organizations and policy makers have shown considerable interests to know the impact assessments of these institutions in order to justify whether the funds are well spent or not. This background has made it expedient for the authors of this study to probe into the issues of impact assessment of microfinance with a view to contributing to the hitherto partial treatment of the subject matter in the literature.

\section{Methodology}

Data used for this study were the primary data collected between July and September, 2014 from the study area: South-West Nigeria. South-West Nigeria is one of the six geo-political zones of Nigeria. South-West geo-political zones has a population of 27,722,432 people out of the Nation's total population of 140,431,790 (National Population Census, 2006). The zone has six states comprising Ekiti, Lagos, Ogun, Ondo, Osun and Oyo states. The typical vegetation of South-West Nigeria is rainforest with about $12 \%\left(114,271 \mathrm{~km}^{2}\right)$ of Nigeria's coverage space of 923, 768 square kilometers. The zone has the highest concentration of Microfinance Institutions in Nigeria. It accommodates 346 (about 40\%) of the total 870 Microfinance Institutions in six geopolitical zones in Nigeria, while the balance of sixty percent is shared among the remaining five Geo-political zones.

This study used cross-sectional data collected through the structured questionnaire. Purposive survey was used to select three out of six states from the Geographical zone namely Ogun, Oyo and Osun states. 1,145 Questionnaires were distributed to the respondents out of which 1,136 were collected from the sampled respondents. 1,134 were effectively used for the analyses; comprising 594 loan beneficiaries and 540 non-beneficiaries. The loan beneficiaries are those individuals who obtained microfinance loan in at least previous three years. Non-Beneficiaries are those who have similar characteristics with the latter and applied for microfinance loan in the previous three years but could not obtain approval for the loan. Being an individual beneficiary of microfinance loan is regarded as a derived one from the household perspective. In essence, if one or more members of a household obtain microfinance loan, the entire household is classified as beneficiary (Ashraf \& Ibrahim, 2014).

Data collected included the demographic characteristics of the respondents, business and owner's profile, consumption expenditure, loan procurement procedure, assets and business management among others. In addition, operators of Microfinance Institutions in the study area were also interviewed on their mode of operations, problems faced on the clientele and the assistance required from the Government.

\section{Empirical Results}

Demographics and socio-economic characteristics of the rural poor collected from the study area through the surveyed questionnaire are depicted in Table 1. From the total sample size of 1,134 household heads, 594 (52.4\%) are microfinance loan beneficiaries and the remaining $540(47.6 \%)$ are non-beneficiaries. In terms of gender, the sample comprises $53 \%$ males and $47 \%$ females. About $51 \%$ of microfinance loan beneficiaries are males while almost $49 \%$ are females; whereas about $56 \%$ of non-beneficiaries are males with around $44 \%$ females. This shows that both loan beneficiaries and non-beneficiaries have similar gender characteristics.

With respect to Education level, the sampled respondents are grouped into five categories. This consists of those with no formal education, those with primary education, those who attended High School, Graduates of National Diploma and those who are degree holders. As depicted in Table 1, majority of the respondents have obtained education in one form or the other; about $14 \%$ of the total respondents reported no formal education. The proportion of no formal education for the microfinance loan beneficiaries is $12.5 \%$, lower than that for the non-beneficiaries (15.4\%). About $87.5 \%$ of the microfinance loan beneficiaries and $84.6 \%$ of non-beneficiaries have acquired primary education or more (including High School, National Diploma and Higher Diploma/University degree). Moreover, the proportion of microfinance loan beneficiaries with post High School education (Diploma and Degree) is higher than that of non-beneficiaries (38.7\% against 30.9\%). 
With regards to age, the respondents have age range of between 20 and above 60 years old. The overall mean age for the sample is around 39 years. This shows that most of the respondents are still active and young enough to exhibit their entrepreneurship. When grouped into different age categories, the vast majority of both microfinance loan beneficiaries and non-beneficiaries fall into similar age bracket of $31-40$ years old (46.7\% and $49.5 \%$ respectively).

The field survey revealed that a large proportion of the respondents are married $(75.6 \%$ of microfinance loan beneficiaries and $80.2 \%$ of non-beneficiaries). This shows that most of the sampled respondents are responsible to their families and have the tendency to cater for them.

The distribution of the respondents to religion categories is similar for both Islam and Christianity. Only $2.4 \%$ of microfinance loan beneficiaries have Traditional belief while that of non-beneficiaries is $7.6 \%$.

The skill/Experience in business entrepreneurship is grouped into four categories. The vast majority of the respondents have acquired less than 10 years business experience. While the proportion of the microfinance loan beneficiaries that belong to this category is almost $80 \%$ that of non-beneficiaries is $68 \%$.

As shown in Table 1, monthly income for the household head is grouped into five levels. The monthly income for most of the microfinance loan beneficiaries reported is above 30,000 Nigerian Naira (28.3\%) while that of the non-beneficiaries group respondents is between 21,000 - 30,000 Nigerian Naira. Also the household head monthly expenditure of microfinance loan beneficiary group respondents is mainly less than 5,000 Nigerian Naira (41.1\%); most of the household heads' monthly expenditure in the non-beneficiary respondents group falls between 5,000-10,000 Nigerian Naira (33.2\%).

The proportion of the household size is similar in the sampled survey. About $44 \%$ of microfinance loan beneficiaries have 2-4 persons as members of the household while almost $68 \%$ of non-beneficiaries have $2-4$ persons as members of their households. The survey also revealed that mostly less than 2 persons work and earn income $(49.1 \%)$ in the microfinance loan beneficiary respondents group; while from 2-4 members of the non-beneficiary respondents group mostly work and earn income (64.9\%).

Table 1. Characteristics of Sample (Beneficiaries and Non Beneficiaries)

\begin{tabular}{cccc}
\hline & $\begin{array}{c}\text { Non-Beneficiary } \\
\mathrm{N}_{0}=540(47.6 \%) \\
\% \text { to } \mathrm{N}_{0}\end{array}$ & $\begin{array}{c}\text { Beneficiary } \\
\mathrm{N}_{1}=594(52.4 \%) \\
\% \text { to } \mathrm{N}_{1}\end{array}$ & $\begin{array}{c}\text { Total Sample } \\
\mathrm{N}_{3}=1134(100 \%) \\
\text { Subtotal } \% \text { to } \mathrm{N}_{4} \\
\mathrm{~N}_{4}=\mathrm{N}_{0}+\mathrm{N}_{1}\end{array}$ \\
\hline Demography & & \\
Gender & & & \\
Male & 55.6 & 50.7 & 53 \\
Female & 44.4 & 49.3 & 47 \\
Total & 100 & 100 & 100 \\
\hline Education Level & & & 13.8 \\
No formal education & 15.4 & 12.5 & 23.6 \\
Primary education & 28.1 & 19.5 & 27.5 \\
High school & 25.6 & 29.3 & 19.5 \\
National Diploma & 18.7 & 20.2 & 15.5 \\
Higher Diploma/University & & & 100 \\
degree & 12.2 & 18.5 & 16.1 \\
Total & 100 & 100 & 48 \\
Age (in years) & & & 26.2 \\
20 - 30 & 14.3 & 17.1 & 7.6 \\
31 - 40 & 49.5 & 46.7 & 2.7 \\
41 - 50 & 27.3 & 25.1 & 100 \\
51 - 60 & 6.5 & 8.7 & 19.22 \\
$>60$ & 2.4 & 2.6 & \\
Total & 100 & 100 & \\
Mean Age & 39.25 & 39.19 & \\
\hline & & & \\
\hline
\end{tabular}




\begin{tabular}{cccc}
\hline Marital Status & 11.3 & 17.0 & 14.3 \\
Single & 80.2 & 75.6 & 77.8 \\
Married & 5.9 & 3.9 & 4.9 \\
Divorced & 1.9 & 3.2 & 2.6 \\
Widow & .7 & .3 & .5 \\
Widower & 100 & 100 & 100 \\
Total & & & 42.5 \\
Religion & 44.2 & 40.8 & 52.7 \\
Islam & 48.2 & 56.8 & 4.8 \\
Christianity & 7.6 & 2.4 & 100 \\
Traditional & 100 & 100 & \\
Total & & & \\
\hline
\end{tabular}

Table 2. Characteristics of Sample (Beneficiaries and Non Beneficiaries) contd

\begin{tabular}{|c|c|c|c|}
\hline \multirow[b]{2}{*}{ Total Sample } & \multicolumn{2}{|c|}{ Non-Beneficiary } & \multirow{2}{*}{$\begin{array}{l}\text { Beneficiary } \\
\qquad \mathrm{N}_{3}=1134(100 \%) \\
\text { Subtotal } \% \text { to } \mathrm{N}_{4} \\
\mathrm{~N}_{4}=\mathrm{N}_{0}+\mathrm{N}_{1}\end{array}$} \\
\hline & $\begin{array}{c}\mathrm{N}_{0}=540(47.6 \%) \\
\% \text { to } \mathrm{N}_{0}\end{array}$ & $\begin{array}{c}\mathrm{N}_{1}=594(52.4 \%) \\
\% \text { to } \mathrm{N}_{1}\end{array}$ & \\
\hline \multicolumn{4}{|c|}{ Household Profile } \\
\hline \multicolumn{4}{|c|}{ Skill/Experience in Business (in years) } \\
\hline$\leq 10$ & 68.1 & 80. & 74.3 \\
\hline $11-20$ & 29 & 18.4 & 23.5 \\
\hline $21-30$ & 2.3 & 1.7 & 2. \\
\hline$>30$ & .8 & .2 & .5 \\
\hline Total & 100 & 100 & 100 \\
\hline Mean Experience in Business & 9.40 & 7.81 & 8.57 \\
\hline \multicolumn{4}{|c|}{ Household Monthly Income in Naira(Head) } \\
\hline Less than N5000 & 13.1 & 14.1 & 13.7 \\
\hline N5000 - N10000 & 11.7 & 21.0 & 16.6 \\
\hline N11000 - N20000 & 24.4 & 19.2 & 21.7 \\
\hline N21000 - N30000 & 27.2 & 17.3 & 22.0 \\
\hline Above N30000 & 23.5 & 28.3 & 26.0 \\
\hline Total & 100 & 100 & 100 \\
\hline \multicolumn{4}{|l|}{ Household expenditure (Head) } \\
\hline Less than N5000 & 24.9 & 41.1 & 33.4 \\
\hline N5000 - N10000 & 33.2 & 24.5 & 28.6 \\
\hline N11000 - N20000 & 30.6 & 18.5 & 24.3 \\
\hline N21000 - N30000 & 5.8 & 7.3 & 6.5 \\
\hline Above N30000 & 5.6 & 8.6 & 7.2 \\
\hline Total & 100 & 100 & 100 \\
\hline \multicolumn{4}{|l|}{ Household Size (members) } \\
\hline Less than 2 persons & 13.5 & 28.5 & 21.4 \\
\hline $2-4$ persons & 67.5 & 44.3 & 55.3 \\
\hline $5-7$ persons & 17.4 & 23.6 & 20.7 \\
\hline 8 - 10 persons & 1.1 & 3.4 & 2.3 \\
\hline Above 10 persons & .4 & .3 & .4 \\
\hline $\begin{array}{r}\text { Total } \\
\end{array}$ & 100 & 100 & 100 \\
\hline \multicolumn{4}{|c|}{ Number of Income Earners (members) } \\
\hline Less than 2 persons & 27.5 & 49.1 & 38.8 \\
\hline 2 - 4 persons & 64.9 & 42.2 & 53.0 \\
\hline $5-7$ persons & 7.4 & 7.8 & 7.6 \\
\hline $8-10$ persons & .2 & 1.0 & .6 \\
\hline Total & 100 & 100 & 100 \\
\hline
\end{tabular}

Source: Field Survey Data (2014) 
Model Specification: The main hypothesis for the study is that microfinance loan contributes to poverty alleviation in the study area.

In order to evaluate the variables that determine Poverty Alleviation together with microfinance loan in the study area, the Binary logistic regression model was explored. Following Gujarati and Porter (2009:555) in the estimation of Logit model, we find the natural log of the equation as follows:

$$
\begin{aligned}
L_{i} & =\ln \left(\frac{P i}{1-P i}\right)=Z_{i} \\
& =\beta_{1}+\beta_{2} X_{i}
\end{aligned}
$$

This implies that $\mathrm{L}$, the $\log$ of the odds ratio, is linear in both $\mathrm{X}$ and the parameters.

It should also be noted that as $\mathrm{P}$ varies from 0 to $1, \mathrm{Z}$ goes from $-\infty$ to $+\infty$.

In the same vein, model for this study can be specified as follows:

$P_{i}=\left(\frac{P i}{1-P i}\right)=\mathrm{f}\left(\mathrm{X}_{1}, \mathrm{X}_{2}, \mathrm{X}_{3}, \mathrm{X}_{4}, \mathrm{X}_{5}, \mathrm{X}_{6}, \mathrm{X}_{7}, \mathrm{X}_{8}\right)$

where,

$P_{i}$ is a binary Dependent variable. $P_{i}=1$; if the person is not poor and $\mathrm{P}_{\mathrm{i}}=0$; if the person is poor. The World Bank's Poverty line Index set at $\$ 1.25$ per day was used as a benchmark to measure the level of poverty. That is, those whose income per day is below the Index were regarded as poor and those people that earn $\$ 1.25$ and above per day were categorized as non-poor.

$\mathrm{X}_{1}=$ Microfinance

$\mathrm{X}_{2}=$ Male

$\mathrm{X}_{3}=$ Age

$\mathrm{X}_{4}=$ Marital

$\mathrm{X}_{5}=$ Education level

$\mathrm{X}_{6}=$ Living Standard

$\mathrm{X}_{7}=$ Health Standard

$\mathrm{X}_{8}=$ Household size

In this model, Poverty Alleviation is considered as Dependent variable, while Microfinance, Male, Age, Marital, Education level, Living Standard, Health Standard and Household size are considered as explanatory or independent variables.

Table 2 shows the empirical results of microfinance loan and Poverty Alleviation model through the estimated logistic regression analysis. The results identify the explanatory variables determining the Poverty Alleviation with microfinance loan as a focus variable. In the overall results, the logistic model correctly classified almost 80 percent of the sample cases as the percentage accuracy in classification (PAC); and six out of the eight explanatory variables are found to be statistically significant. It is therefore safe to conclude that the explanatory power of the logit regression model can be satisfactorily used to explain the likelihood of evaluating the role of microfinance loan in alleviating poverty in the study area. The full model comprising all the independent variables (predictors) was statistically significant; the chi $^{2}$ is 558.9 with 8 degrees of freedom.

The model, which has Poverty Alleviation as its dependent variable aims at predicting the variables that determine the reduction of poverty with microfinance as a variable of interest in South-West Nigeria. To this end, specific characteristic variables of the respondents like Male, Age, Marital, education level and household size were included in the explanatory variables. This goes in line with some previous literature on the subject matter that included such social demographic variables to explain the dependent variable (for example, Arun et al., 2006; Ifelunini \& Wosowei, 2012; Joseph \& Imhanlahimi, 2011).

In Table 2, results of the model predicts that only six of the independent variables (microfinance loan, Male, Living Standard, Health Standard, Marital and household size) are statistically significant and made reliable contributions to predict the poverty alleviation level. The remaining two (Age and Education) did not make significant contribution to the model; hence, they were not reported in the model. The model predicts that being a microfinance beneficiary may likely reduce the odd ratio of poverty alleviation by 45 percent other factors remain the same. This can be explained in the situation of new beneficiaries who are still facing teething problems in operating their enterprises. It is therefore expedient for Microfinance operators to establish enough training on entrepreneurship for beneficiaries of their loan. The odds ratio increases the likely reduction in 
poverty of male microfinance beneficiary by almost 84 percent than that of female counterpart other factors remain same. This is consistent with the views of Okojie et al. (2009) who confirm in their research that women are constrained to access microfinance loan because they lack collateral like land and other property which their male counterparts possess; and have no freedom to obtain loan without the consent of their husband. However, the odds ratio increases the likely poverty alleviation of married household of microfinance beneficiary by 30 percent than that of single beneficiary other factors remain unchanged. In the same vein, for a proportionate increase in the living standard of microfinance loan beneficiary, the odd ratio increases the poverty alleviation by 92 percent other factors remain constant. This confirms the direct relationship between poverty alleviation and living standard. Moreover, for a likely increase in the health standard of microfinance loan beneficiary, there is likelihood of odd ratio of poverty alleviation to reduce by 47 percent and vice-versa, other factors held constant. This can be explained by the fact that the stress and challenges of the well to do entrepreneurs always have negative impact on their health status as little or no time would be left for leisure and sports. However, for a proportionate increase in household size, there is probability that the odds ratio increases by 68 percent the likelihood of increasing the poverty alleviation, other things remain the same. This can be explained by the fact that increase in household size can generate cheap labour for the household and increase the future per capital income. Above findings suggest that microfinance makes significant contributions to poverty alleviation. This assertion is consistence with the findings of Khandker (2005) and Okpara (2010) to mention just two.

The Model estimates shown in Table 2 confirm high significance of the explanatory variables of Microfinance, Male, Living Standard, Health Standard and Household size with the overall significance level at 0.000 . This confirms the fact that the model rejects the null hypothesis that the estimates of the parameters of the model equal to zero at 1 percent level of significance. In other words, there is more than 99 percent chance that the parameters of the variable estimates are not zero.

\begin{tabular}{|c|c|c|c|c|}
\hline $\begin{array}{l}\text { Explanatory } \\
\text { Variables }\end{array}$ & $\begin{array}{l}\text { Estimated } \\
\text { Coefficients }\end{array}$ & $\begin{array}{l}\text { Odds } \\
\text { Ratio }\end{array}$ & $\begin{array}{l}\text { Standard } \\
\text { Error }\end{array}$ & $\begin{array}{l}\text { Marginal }^{\mathrm{a}} \\
\text { Effect }\end{array}$ \\
\hline Microfinance & $-0.603^{* * *}$ & 0.547 & $0 . .098$ & -0.120 \\
\hline Male & $0.607^{* * *}$ & 1.835 & 0.306 & 0.122 \\
\hline Age & -0.005 & 0.995 & 0.011 & -.081 \\
\hline Marital & $0.265^{*}$ & 1.303 & 0.209 & 0.199 \\
\hline Education & 0.075 & 1.078 & 0.076 & 0.090 \\
\hline Living Standard & $0.653^{* * *}$ & 1.922 & 0.085 & 4.598 \\
\hline Health Standard & $-0.630^{* * *}$ & 0.532 & 0.057 & -1.178 \\
\hline Household size & $0.519^{*+*}$ & 1.681 & 0.216 & 0.423 \\
\hline \multicolumn{2}{|c|}{ McFadden R-Squared (Pseudo R²) } & \multicolumn{2}{|c|}{0.364} & \\
\hline \multicolumn{2}{|l|}{ Correctly Predicted (\%) } & \multicolumn{2}{|c|}{79.79} & \\
\hline \multicolumn{2}{|l|}{ Log Likelihood } & \multicolumn{2}{|c|}{-487.945} & \\
\hline \multicolumn{2}{|c|}{ LR statistics: Chi-Squares (Sig.) } & \multicolumn{2}{|c|}{$558.90(000)$} & \\
\hline \multicolumn{2}{|l|}{ Degree of Freedom } & 8 & & \\
\hline
\end{tabular}

Note

${ }^{a}$ Marginal effect is estimated at mean value

${ }^{* * *}=$ significant at $1 \% ;{ }^{* *}=$ significant at $5 \%$ level; ${ }^{*}=$ significant at $10 \%$ level

Source: Result of Data analysed (2014)

Figure 2. Result of logit estimates on evaluation of role of microfinance on poverty alleviation 


\section{Conclusion}

With the enumeration of the important role of microfinance in poverty reduction, the study projected into the factors that evaluate poverty alleviation of the poor in the South-West Nigeria. Eight explanatory variables were explored in the model and Binary Logistic regression Model was used to analyse the model. Six of the explanatory variables (microfinance loan, Male, Living Standard, Health Standard, Marital and household size were found to be statistically significant in determining the Poverty Alleviation of the microfinance loan beneficiaries in Nigeria.

In the final analysis, it is postulated that in order to enable microfinance to achieve the objective of poverty reduction, the Government must create an enabling environment and establish regulatory laws that will guide the efficiency of Microfinance Institutions (MFIs). Concerted efforts should be made towards the provision of supportive services like education and training on entrepreneurship, increase in health facilities and provision of other social services for unemployed, poor and those who are vulnerable to poverty. It is also important for the MFIs to create public enlightenment programmes that would spread their role as development agents for poverty reduction and encourage the poor people who are supposed to be their target audience.

\section{References}

Arun, T., Imai, K., \& Sinha, F. (2006). Does the Microfinance Reduce Poverty in India? Propensity Score Matching based on a National-level Household Data. The University of Manchester Economics Discussion Paper: EDP-0625, September.

Asghar, N. (2012). Microfinancing for Poverty Reduction: An Empirical Study of Rural Areas of Tehsil Gujrat-Pakistan. International Journal of Advances in Management and Economics, 1(4), 14-19. Retrieved from http://www.managementjournal.info

Ashraf, M. A., \& Ibrahim, Y. B. (2014). Poverty Alleviation and Identifying the Barriers to the Rural Poor Participation in MFIs: A Case Study in Bangladesh. Journal of Economic Cooperation and Development, 35(3), 99-132.

Basir, M. K., Amin, A., \& Naeem, M. K. (2010). Micro-credit and Poverty Alleviation in Pakistan. World Applied Sciences Journal, 8(11), 1381-1386.

Chaudhry, I. S. (2009). Poverty Alleviation in Southern Punjab (Pakistan): An Empirical Evidence from the Project Area of Asian Development Bank. International Research Journal of Finance and Economics, 23(23), 23-32.

Duku, O. P. (2002). A critical assessment of Jamaica's national poverty eradication programme. Journal of International Development, 14(6), 773-788. http://dx.doi.org/10.1002/jid.923

El-Komi, M. S. (2010). Poverty Alleviation Through Microfinance and Implications on Education. Dissertation Publishing UMI13421471, ProQuest.

Goel, G., \& Rishi, M. (2012). Promoting Entrepreneurship to Alleviate Poverty in India: An Overview of Government Schemes, Private- Sector Programs, and Initiatives in the Citizens' Sector. Thunderbird International Business Review, 54(1), 45-57. http://dx.doi.org/10.1002/tie.21437

Green, C. J., Kirkpatrick, C. H., \& Murinde, V. (2006). Policy Arena Finance for Small Enterprise Growth and Poverty Reduction in Developing countries. Journal of International Development, 18, 1017-1030. http://dx.doi.org/10.1002/tie.21437

Gujarati, N., \& Porter, D. C. (2009). Basic Econometrics. Singapore: McGraw-Hill.

Hulme, D., \& Mosley, P. (1997). Finance for the Poor or the Poorest? Financial Innovation, Poverty and Vulnerability. Cited in Role of Microcredit in Rural Poverty Alleviation: A Case study of Grameen Bikas Bank in Eastern Development Region, Nepal, A dissertation submitted in partial fulfillment of the requirements for the degree of Doctor of Philosophy at George Mason, University by Hari Bansha Dulal 2007.

Ifelunini, I. A., \& Wosowei, E. C. (2012). Does Micro Finance Reduce Poverty among Women Entrepreneurs in South-South Nigeria? Evidence from Propensity Score Matching Technique. European Journal of Business and Management, 4(21), 76-87.

Joseph, I. E., \& Imhanlahimi, J. E. (2011) Access and impact assessment of micro finance banks on rural poor in Nigeria: a case study of Edo state. Indian Journal of Economics and Business, 10, 327-359.

Kalirajan, K., \& Singh, K. (2009). The pace of poverty reduction across the globe: an exploratory analysis. 
International Journal of Social Economics, 36(6), 692-705. http://dx.doi.org/10.1108/03068290910956921

Khandker, S. R. (2005). Microfinance and Poverty: Evidence Using Panel Data from Bangladesh. The World Bank Economic Review, 19(2), 263-286. http://dx.doi.org/10.1093/wber/lhi008

Muller, C., \& Bibi, S. (2010). Refining Targeting against Poverty. Evidence from Tunisia. Oxford Bulletin of Economics and Statistics, 72(3), 381-410. http://dx.doi.org/10.1111/j.1468-0084.2010.00583.x

National Bureau of Statistics. (2012). Nigeria Poverty Profile 2010. Retrieved from $\mathrm{http} / / /$ reliefweb.int/report/nigeria/nigeria-poverty-profile-2010-report

National Planning Commission. (2010). 2010 Performance Monitoring and Evaluation Report (pp. 1-161).

Okojie, C. E. E., Eghafona, K., Osaghae, G., Monye-Emina, A., \& Ehiakhamen, J. O. (2009). Institutional Environment and Access to Microfinance By Self-employed Women in the Rural Areas of Edo State. Nigeria, Nigeria Strategy Support Program (NSSP) Background Paper No. NSSP 003, September.

Okpara, G. C. (2010). Microfinance Banks and Poverty Alleviation in Nigeria. Journal of Sustainable Development in Africa, 19(6), 177-191.

Roslan, A., \& AbdKarim, M. Z. (2009). Determinants of Microcredit Repayment in Malaysia: The Case of Agrobank. Humanity and Social Sciences Journal, 4(1), 45-52.

Smith, N. (2010). Economic inequality and poverty: where do we go from here? International Journal of Sociology and Social Policy, 30(3/4), 127-139. http://dx.doi.org/10.1108/01443331011033328

Ssewamala, F. M., Sperber, E., Zimmerman, J. M., \& Karimli, L. (2010). The potential of asset-based development strategies for poverty alleviation in Sub-Saharan Africa. International Journal of Social Welfare, 19(4), 433-443. http://dx.doi.org/10.1111/j.1468-2397.2010.00738.x

Tang, S., \& Bhatt, N. (2002). Determinants of Repayment in Microcredit: Evidence from Programmes in the United States. International Journal of Urban and Regional Research, 26(2), 360-376. http://dx.doi.org/10.1111/1468-2427.00384

Taylor, J. G., \& Xiaoyun, L. (2012). China's Changing Poverty: A Middle Income Country Case Study. Journal of International Development, 24, 696-713. http://dx.doi.org/10.1002/jid.2862

Todaro, P. T., \& Smith, S. C. (2011). Economic Development. England: Pearson.

Yang, B., Jialali, P., \& Wei, X. (2011). Microfinance in China's Poor Area and Its Impact to Loan Type Evidence from Xinjiang Uygur Autonomous Region. 2011 Fourth International Conference on Business Intelligence and Financial Engineering, 486-490. http://dx.doi.org/10.1109/BIFE.2011.82

Yusuf, M. B. O., Shirazi, N. S., \& MatGhani, G. (2013). The impact of Pakistan Poverty Alleviation Fund on Poverty in Pakistan: an emperical analysis. Middle-East Journal of Scientific Research,13(10), 1335-1344.

\section{Copyright}

Copyright for this article is retained by the author(s), with first publication rights granted to the journal.

This is an open-access article distributed under the terms and conditions of the Creative Commons Attribution license (http://creativecommons.org/licenses/by/3.0/). 